$14^{\text {th }}$ Conf. Agric. Develop. Res., Fac. of Agric., Ain Shams Univ.,

March, 2019, Cairo, Egypt

Special Issue, 27(1), 501 - 509, 2019

Website: http://strategy-plan.asu.edu.eg/AUJASCI/

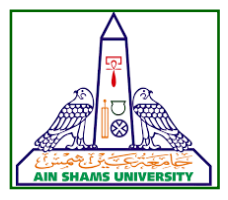

\title{
ASSESSMENT OF GRAPE SEEDS AS A SOURCE OF ANTIOXIDANT COMPOUNDS
}

Zeinab, M. Hassan ${ }^{1}$, Osheba, A.S. ${ }^{1}$, Khallaf, M.F. ${ }^{2}$ and Abdel Fattah, A.A. ${ }^{2}$

1. Meat and Fish Technology Research Dept., Food Technology Research Institute, Agricultural Res. Center, Giza, Egypt

2. Food Sci., Dept., Fac. of Agric., Ain Shams Univ., P.O. Box 68, Hadyek Shoubra11241, Cairo, Egypt

*Corresponding author: zeinabmohamed32@yahoo.com

\begin{abstract}
The grape seeds extracted with various organic solvents (methanol, ethanol, acetone and chloroform) either pure (100\%) or mixed with 30,50 and $50 \%$ water (except chloroform) were evaluated for its content of antioxidant compounds; i.e. phenolics and flavonoids (by HPLC technique) and/or antioxidant activities (by DPPH test). The extraction yield was ranged between $6-10 \%$ depending on solvent type and significantly increased by mixing with water with various percentages. Total phenolics, total flavonoids and antioxidant activity of grape seed extracts were affected by type of solvent. The highest total phenolic compounds and total flavonoids was recorded in methanol $70 \%$ extract, while the lowest one was in water $100 \%$ extract.
\end{abstract}

Keywords: Grape seed extract, Antioxidant compounds, HPLC technique, DPPH test, Antioxidant activity, Extraction

\section{INTRODUCTION}

Grape seeds extract (GSE) was recommended for using as antioxidant in confectionery and fishery products; i.e. as a food additive but, in Japan it is also used as a healthy food material and its consumption is about $100000 \mathrm{~kg} / \mathrm{year}$. The solid wastes that generated by wine industry reaches $30 \%$ of used material mainly grape pomace containing seeds, skin, pulp and stem (Teixeira et al 2014, Dwyer et al 2014). High levels of valuable compounds such as dietary fibers, seeds oil and phenolic compounds are still remain after processing in grape pomace (González-Centeno et al 2013). Such phenolics have a great potential owing to their antioxidant capacity and health benefits for coronary diseases by inhibiting low-density lipoproteins (Otero-Pereja et al 2015). This study tries to assess and identify the antioxidant compounds that highly found in grape seeds extracted with various organic solvents; i.e. methanol, ethanol, acetone and chloroform either pure (100\%) or mixed with 30, 50 and 50\% water (except chloroform).

\section{MATERIAL AND METHODS}

\section{Materials}

Grape pomace (Vitisvinifera) was obtained from Ganaklis Company for Beverages at Alexandria governorate.

\section{Preparation of grape seeds extracts}

Extracts were prepared according Rehman (2006). Grape pomace (GP) seeds was washed and dried in a hot air oven at $40^{\circ} \mathrm{C}$ for 16 hours. The dried grape pomace was separated to skin and seeds. Seeds were ground into a fine powder then sieved through an 80 -meshsiever. $10 \mathrm{gm}$ of ground sample were extracted with $100 \mathrm{ml}$ of different organic solvents (100 and 50\% ethanol; 100 and $70 \%$, methanol; 100 and 50\% acetone; 100 
distilled water or $100 \%$ chloroform) overnight in a shaker at room temperature. The grape seed extracts were filtered and the residues were reextracted under the same conditions. The filtrate was evaporated in a rotary evaporator $(\mathrm{BÜCHI}$ Rotavapor R-124 Germany) 40ㄷ. All grape seed extracts were dried in oven drier at $40^{\circ} \mathrm{C}$ then convert to powder form, except waterextractwasfreeze dried at $-40^{\circ} \mathrm{C}$, volume flow rate $30 \mathrm{~m}^{2} / \mathrm{h}$ and ultimate pressure $4 \times 10^{-2} \mathrm{~Pa}$. (Snijders Scientific b.v., Holland).

\section{Analytical methods}

\subsection{Proximate composition}

Moisture, fat, protein, ash and crude fiber were determined as mentioned in A.O.A.C. (2012).

\subsection{Determination of antioxidant compounds for waste extracts}

\subsubsection{Determination of total phenolic content (TPC)}

The total phenolic content was determined according to the method reported by Julkunen-Titto (1985). Aliquots of $50 \mu \mathrm{l}$ of each diluted extract were mixed with $1950 \mu \mathrm{l}$ water in a $10 \mathrm{ml}$ test tube. One $\mathrm{ml}$ of Folin-Ciocalteu reagent was added and the test tube was vigorously shaken. Immediately, $5 \mathrm{ml}$ of $20 \%$ sodium carbonate solution was added, the volume of the mixture was brought up to $10 \mathrm{ml}$ and shaken thoroughly again. After $20 \mathrm{~min}$, the absorbance of mixture was read at $735 \mathrm{~nm}$ by spectrophotometer (model: CT2200-s/n: RE1310004 - Germany). Phenolic content of extracts was calculated on the basis of the standard curve for gallic acid. The results were expressed as mg gallic acid equivalents per $100 \mathrm{~g}$ dry matter.

\subsubsection{Determination of total flavonoids}

Flavonoids content was measured according to the $\mathrm{AlCl} 3$ method (Huang et al 2006). Each extract $(0.5 \mathrm{ml})$ was mixed with $1.0 \mathrm{ml}$ of $2 \%$ methanolic $\mathrm{AlCl}_{3} \cdot 6 \mathrm{H}_{2} \mathrm{O}$, and absorbance was measured after $10 \mathrm{~min}$ at $430 \mathrm{~nm}$. The content of flavonoids was calculated on the basis of the calibration curve of quercetin and expressed as mg quercetin per 100 g dry matter.

\subsection{Antioxidant activity of grape seed extracts}

\subsubsection{DPPH scavenging assay}

The DPPH method was carried out as described by Brand- Williams etal (1995). The decrease in theabsorbance of $100 \mu \mathrm{M} \mathrm{DPPH}$ - radicals $(2.9 \mathrm{~mL})$ dissolved in $80 \%$ methanol was evaluated at $515 \mathrm{~nm}, 30 \mathrm{~min}$ after addition ofeach extract. Total antioxidant activity (on a $\mathrm{dw}$ basis)was also expressed in $\mu \mathrm{Mol} / \mathrm{g}$ of TEAC.

\subsection{Fractionation of phenolic compounds and flavonoids by HPLC}

Phenolic compounds and flavonoids were performed by HPLC analysis using the method described by Dragovic-Uzelac et al (2005). Beckman model equipped by double piston pump 126 with Fluorescence detector LC 240 (Perkin Elmer); pump for reaction (Dioxin); Derivatisering tube 10 $\mathrm{m} \times 0.33 \mathrm{~mm}$; Data handling system (Software Gold); Column Supelcosil LC-18-DB, $25 \mathrm{Cm} \times 4.6$ $\mathrm{mm}, 5 \mu \mathrm{m}$; Injector 20 $\mu \mathrm{l}$ (Beckman). Injection was carried out at wave lengths $280 \mathrm{~nm}$ for separation.

\section{RESULTS AND DISCUSSION}

\section{1- Proximate composition of grape seeds}

On dry weight basis, Table (1) showed grape seeds had $7.68,10.59,2.28,45.61$ and $33.84 \%$ of protein, either extract, ash, fibers and carbohydrates, respectively. These findings go in parallel with those of Ovcharova et al (2016).

Table 1. Proximate composition of grape seeds

\begin{tabular}{|c|c|c|}
\hline \multirow{2}{*}{ Parameter (\%) } & \multicolumn{2}{|c|}{ Grape seeds } \\
\cline { 2 - 3 } & $\mathrm{WW}^{\star}$ & $\mathrm{DW}^{\star *}$ \\
\hline Moisture & 6.82 & -- \\
Protein & 7.15 & 7.68 \\
Ether extract & 9.87 & 10.59 \\
Ash & 2.13 & 2.28 \\
Fibers & 42.50 & 45.61 \\
Carbohydrates $^{\star \star *}$ & 31.53 & 33.84 \\
\hline
\end{tabular}

* WW: Wet weight basis

** DW: Dry weight basis

${ }^{* * *}$ Calculated by difference

\section{Extraction yield of grape seeds}

Extraction yield grape seeds as affected by solvents type presented in Table (2) were signifi- 
cantly $(P \leq 0.05)$ affected by solvents type. Extraction yield for all solvent ranged from 6.0 to $14.50 \%$. These results are in agreement with those obtained by Vayupharp and Laksanalamai (2012). The pure solvents such as water, ethanol, methanol, aceton and chloroform that used for extracting grape seeds gave the extract yield of $8.10,10.0$, $8.0,6.0$ and $8.50 \%$, respectively. While, by using mixture of pure solvent (methanol, ethanol or acetone) with water for extracting, the yield was 10.00 , 11.5 and $14.5 \%$, respectively.

Table 2. Extraction yield of grape seeds as affected by solvents type

\begin{tabular}{|l|c|}
\hline Solvent type (v:v) & Extraction yield (\%) \\
\hline Water (100\%) & $8.10^{\mathrm{d}}$ \\
Ethanol (100\%) & $10.0^{\mathrm{c}}$ \\
Ethanol: Water, 50:50 & $11.50^{\mathrm{b}}$ \\
Acetone 100\% & $6.00^{\mathrm{e}}$ \\
Acetone: Water, 50:50 & $14.50^{\mathrm{a}}$ \\
Methanol 100\% & $8.00^{\mathrm{d}}$ \\
Methanol: Water, 70: 30 & $10.00^{\mathrm{c}}$ \\
Chloroform 100\% & $8.50^{\mathrm{de}}$ \\
\hline LSD at 0.05 level & 0.50 \\
\hline
\end{tabular}

Mean values followed by different letters in the column are significantly different $(\mathrm{P} \leq 0.05)$.

Percent of yield extract was depended on type of components in grape seeds and polarity of solvent. The extraction with pure ethanol gave the highest yield (10.0\%). The lowest one $(6.0 \%)$ was recorded for pure acetone, this might be due to low capability of acetone to extract polar compounds. When $50 \%$ of water was added to acetone, the extraction yield was significantly increased from 6.0 to $4.5 \%$. This could be explained by increasing polarity of an aqueous mixture of acetone for extracting more polar compounds in grape seeds. Also, the extraction yield was also significantly increased from 10 to $11.50 \%$ for ethanol and from 8.0 to $10.0 \%$ for methanol when 50 and $30 \%$ of water were added, respectively. The highest yield was observed with acetone $50 \%$ followed by ethanol $50 \%$. These results indicated that $50 \%$ acetone or $50 \%$ ethanol are the best solvents to extract material from grape seeds.

\section{Total phenolic, total flavonoids and antioxi- dant activity of grape seeds}

Total phenolic compounds, total flavonoids and antioxidant activity of grape seeds as affected by type of solvent were given in Table (3). Total phe- nolic compounds and total flavonoids of grape seed extracts were significantly $(P \leq 0.05)$ affected by solvent type. Total phenolic compounds and total flavonoids of all grape seed extracts were ranged from 3.558 to $9.501 \mathrm{mg}$ gallic acid $/ \mathrm{g}$ and 3.260 to $6.707 \mathrm{mg}$ quercetin/g dry matter, respectively. These results are in agreement with those reported by Librán et al (2013) found that total phenolic compounds of grape seed ranged from 4.58 to $28.06 \mathrm{mg} \mathrm{GAE} / \mathrm{g}$ dry sample, depending on the extraction conditions. Also,Nageb (2015) found that total phenolic compounds in grape seeds ranged from 115.28 to $324.75 \mathrm{mg}$ gallic acid/ $100 \mathrm{gm}$ lower than those obtained by Casazza et al (2010) who found the highest content in total polyphenol are o-diphenols and flavonoids of grape seeds (108.3, 47.0mg gallic acid equivalent/g and $47.2 \mathrm{mg}$ catchin equivalent/g on dry weight, respectively) and also Rockenbach et al (2011) reported that total phenolic compounds of grape pomace was $74.75 \mathrm{mg} \mathrm{GAE} / \mathrm{g}$ higher than those of Abdrabba and Hussein (2016) who found that total phenolic content of pulps, seeds and peels of red grape was 11.65, 73.59 and $13.73 \mathrm{mg}$ $\mathrm{GAE} / 100 \mathrm{~g}$, respectively.

Table 3. Total phenolic, total flavonoids and antioxidant activity of grape seeds as affected by type of solvents

\begin{tabular}{|c|c|c|c|}
\hline Solvent type (v:v) & \begin{tabular}{|c} 
Total phenol- \\
ic com- \\
pounds \\
$(\mathrm{mg} / \mathrm{g})$
\end{tabular} & $\begin{array}{c}\text { Total fla- } \\
\text { vonoids } \\
(\mathrm{mg} / \mathrm{g})\end{array}$ & $\begin{array}{c}\text { DPPH } \\
\mu \text { MolTrolo } \\
\text { xeq/ gm }\end{array}$ \\
\hline Water $100 \%$ & $3.558^{\mathrm{g}}$ & $3.260^{\dagger}$ & $198.62^{g}$ \\
\hline Ethanol $100 \%$ & $5.804^{\text {ef }}$ & $4.189^{\mathrm{e}}$ & $504.652^{\mathrm{e}}$ \\
\hline $\begin{array}{l}\text { Ethanol: Water, } \\
50: 50\end{array}$ & $8.949^{b}$ & $6.398^{b}$ & $636.50^{\mathrm{b}}$ \\
\hline Acetone $100 \%$ & $4.629^{\dagger}$ & $3.433^{\dagger}$ & $449.82^{\dagger}$ \\
\hline $\begin{array}{l}\text { Acetone: Water, } \\
50: 50\end{array}$ & $7.657^{\mathrm{c}}$ & $6.228^{b}$ & $566.32^{c}$ \\
\hline Methanol 100\% & $6.824^{d}$ & $6.060^{c}$ & $577.19^{c}$ \\
\hline $\begin{array}{l}\text { Methanol: Water, } \\
70: 30\end{array}$ & $9.501^{\mathrm{a}}$ & $6.707^{\mathrm{a}}$ & $702.37^{\mathrm{a}}$ \\
\hline Chloroform $100 \%$ & $6.085^{\mathrm{e}}$ & $5.126^{d}$ & $526.24^{d}$ \\
\hline LSD at 0.05 level & 0.271 & 0.234 & 12.49 \\
\hline
\end{tabular}

Mean values followed by different letters in the column are significantly different $(\mathrm{P} \leq 0.05)$.

The content of total phenolic compounds obtained with pure solvents (acetone, ethanol, chloroform and methanol 100\%) were significantly smaller $(\mathrm{P} \leq 0.05)$ values revealed $4.629,5.804,6.085$ and $6.824 \mathrm{mg}$ gallic acid/g dry matter, respectively. 
These values were significantly increased with added water to the solvents. The increment ratio was $65.41,54.19$ and $39.23 \%$ for acetone, ethanol and methanol when 50,50 and $30 \%$ of water were added, respectively.

Similar trend was also recorded for total flavonoids with corresponding increment ratios of 81.42 , 52.73 and $10.68 \%$. This could be explained by increasing polarity of these solvents for extracting more polar compounds in grape seeds (Vayupharp and Laksanalamai, 2012). The highest total phenolic compounds and total flavonoids was recorded in methanol $50 \%$ extract followed by ethanol $50 \%$ extract as well as acetone $50 \%$ extract with significant differences between them $(P \leq 0.05)$. The lowest total phenolic compounds and total flavonoids were observed for grape seed extracted with $100 \%$ water. These results indicated that the methanol $70 \%$ or ethanol $50 \%$ are the best solvents to extract responsible compounds for the antioxidant effect of grape seed. Similar results were reported by Nageb (2015) who revealed that methanol and ethanol were better than that of acetone and ethyl acetate for tested plant wastes at extraction of phenolic compounds owing to their higher polarity and good solubility of phenolic components from plant materials. Also, many studies showed that methanol was the best extraction solvent to obtain phenolic compounds from different plant materials (Yu et al 2006, Makris et al 2007, Zulkifli et al 2012 and Mohammedelnour et al 2017).

The same Table (3), the antioxidant activity of grape seed extracts was significantly $(P \leq 0.05)$ affected by solvent type. DPPH radical scavenging activity of different grape seed extracts was ranged from 198.62 to $702.37 \mu$ MolTroloxeq/gm dry matter. This range was comparable with the value reported by Rockenbach et al (2011) for grape pomace acidified methanol extract. However, much lower value was reported by Selcuk et al (2011) for grape seed. The difference might be due to the interspecies variation and/or the used extraction solvents as well as the method of antioxidant activity determination.

The antioxidant activity of grape seeds extracted with pure solvents (acetone, ethanol, chloroform and methanol were significantly low $(\mathrm{P} \leq 0.05)$. Values revealed 449.82, 504.652, 526.24 and $577.19 \mu$ MolTroloxeq/gm dry matter, respectively. These values were significantly increased by adding water. The increment ratio was $25.90,26.13$ and 21.69 for acetone, ethanol and methanol when 50,50 and $30 \%$ of water were added, respectively, i.e. grape seed methanol $(70 \%)$ extract and grape seed ethanol (50\%) extract were significantly higher $(\mathrm{P} \leq 0.05)$ antioxidant activity rather than other grape seed extracts. This effect might be attributed to the solvent polarity index. These results indicate that the abovementioned extracts are the best solvents to extract responsible compounds for the antioxidant effect of grape seed (Mohammedelnour et al 2017). The higher antioxidant activity of grape seed methanol (50\%) extract and grape seed ethanol $(70 \%)$ extract might be due to its higher total phenolic and total flavonoids. The correlation between antioxidant activity and total phenolic compounds (TPC) has been widely studied in different fruits and vegetables by using different solvents (Bartolomé et al 2004), Kedage et al 2007, Jayaprakasha et al 2008 and Radovanovic et al 2009). They found a significant correlation between total phenolic compounds and DPPH radical-scavenging activity of the samples extracted with methanol, while there was excellent correlation between TPC and DPPH radical scavenging of the same sample extracted with ethanol. The lowest antioxidant activity (198.62 $\mu$ MolTroloxeq/gm, dm) was recorded for grape seeds extracted with water.

\section{Identification and quantification of individu- al phenolic compounds of grape seed ex- tracts by HPLC technique}

Twenty one phenolic compounds were identified in each grape seed extract (Table 4), but the amount of these compounds were varied according to the type of solvent. Grape seed water extract had the lowest quantity of these compounds. These results agree with that of total phenolic compounds given in Table (3). Vayupharp and Laksanalamai (2012) confirmed that water was considered not an appropriate solvent for extraction comparing with pure acetone or ethanol. PyrogalIol, benzoic, Salycillic, ellagic, catechein, vanillic and $\mathrm{P}-\mathrm{OH}$-benzoic were the most abundant phenolic compounds in grape seed water extract which represented $82.18 \%$ of the total phenolic compounds. Pyrogallol $(30.98 \%$ of the total phenolic compound) was the highest phenolic compound in water extract. However, $\mathrm{P}-\mathrm{OH}$-benzoic (5.91\% of the total phenolic compound) was the lowest one among the most abundant phenolic compounds grape seed water extract.

Gallic, protocatchoic, chlorogenic, catechol, caffeine, caffeic, P-coumaric and 3,4,5-methoxycinnamic were presented in moderate amount in 
Table 4. Identification of phenolic compounds (ppm) of grape seeds as affected by solvent type.

\begin{tabular}{|l|c|c|c|c|c|c|c|c|}
\hline Phenolic compounds & Water & Ethanol & Ethanol & Acetone & Acetone & Methanol & Methanol & Chloroform \\
& Extract & $100 \%$ & $50 \%$ & $100 \%$ & $50 \%$ & $100 \%$ & $70 \%$ & $100 \%$ \\
\hline Gallic & 5.54 & 353.77 & 793.06 & 229.63 & 1013.41 & 852.76 & 159.41 & 280.52 \\
Pyrogallol & 91.7 & 411.08 & 1925.3 & 387.6 & 1720.99 & 1311.12 & 1633.95 & 736.51 \\
4-Aminobenzoic & 1.99 & 13.42 & 30.68 & 24.44 & 72.68 & 170.63 & 82.11 & 31.66 \\
Protocatchoic & 5.95 & 21.00 & 101.43 & 26.42 & 482.46 & 250.09 & 720.05 & 64.54 \\
Chlorogenic & 8.29 & 24.91 & 380.15 & 13.77 & 92.4 & 362.54 & 378.27 & 120.81 \\
Catechein & 21.14 & 57.03 & 582.73 & 145.05 & 759.96 & 567.22 & 826.58 & 234.7 \\
Catechol & 5.72 & 46.57 & 85.269 & 42.1 & 141.84 & 169.4 & 232.74 & 38.17 \\
Caffeine & 4.017 & 32.2 & 327.00 & 69.69 & 345.07 & 429.73 & 543.65 & 98.9 \\
P-OH-benzoic & 17.48 & 128.91 & 1780.31 & 431.51 & 2006.69 & 1475.89 & 2100.33 & 662.63 \\
Caffeic & 4.32 & 21.35 & 51.49 & 7.76 & 38.39 & 53.14 & 206.65 & 15.32 \\
Vanillic & 18.27 & 116.00 & 338.4 & 46.22 & 184.36 & 338.45 & 475.34 & 137.92 \\
P-Coumaric & 3.82 & 14.89 & 68.67 & 3.53 & 62.75 & 48.57 & 38.317 & 10.0 \\
Ferulic & 1.8 & 14.88 & 40.211 & 9.88 & 65.44 & 22.88 & 46.69 & 18.31 \\
Iso-Ferulic & 2.05 & 16.16 & 35.73 & 1.13 & 34.95 & 34.45 & 39.82 & 7.67 \\
Ellagic & 24.4 & 129.2 & 430.12 & 34.62 & 235.49 & 54.93 & 608.48 & 61.83 \\
Alpha-coumaric & 0.379 & 1.51 & 4.76 & 0.59 & 6.26 & 5.46 & 3.94 & 2.57 \\
Benzoic & 36.2 & 185.06 & 802.65 & 38.97 & 336.55 & 431.14 & 598.68 & 118.2 \\
Salysillic & 34.01 & 201.21 & 327.94 & 31.2 & 368.13 & 321.51 & 468.75 & 145.51 \\
3,4,5- methoxycinnamic & 6.72 & 29.7 & 66.01 & 3.87 & 68.09 & 47.56 & 98.9 & 24.93 \\
Coumarin & 1.19 & 8.54 & 24.1 & 4.23 & 46.17 & 28.07 & 31.32 & 12.85 \\
Cinnamic & 0.95 & 1.73 & 3.86 & 0.66 & 9.75 & 6.61 & 7.27 & 1.43 \\
\hline Total PC & 295.94 & 1829.12 & 8199.87 & 1552.87 & 8091.83 & 6982.15 & 9301.25 & 2824.98 \\
\hline
\end{tabular}

grape seed water extract represented $15 \%$ of the total phenolic compounds Iso-ferulic (2.05 ppm), 4aminobenzoic (1.99 ppm), ferulic(1.8 ppm), coumarin (1.19 ppm), alpha-coumaric (0.379 ppm) and cinnamic $(0.95 \mathrm{ppm})$ were presented in trace amount in grape seed water extract consisting $2.8 \%$ of the total phenolic compounds.

Regarding to pure solvents which were used in extraction of phenolic compounds from grape seeds, it could be noticed that grape seed methanol $100 \%$ extract had higher amount of phenolic compounds (6982.15 ppm) than those extracted with chloroform $100 \%$ (2824.98 ppm), ethanol $100 \%$ (1829.12 ppm) and acetone 100\% (1552.87 $\mathrm{ppm})$. This effect may be attributed to the solvent polarity index. In this concern Pinelo et al (2005) reported that methanol solvent expressed the highest selectivity towards phenolic compounds compared with $96 \%$ ethanol and water extracts. P$\mathrm{OH}$-benzoic, pyrogallolngallic, catechein, benzoic, caffeine, chlorogenic, vanillicsalycillic, protocatchoic, 4-aminobenzoic and catechol were the most abundant phenolic compounds in grape seed methanol $100 \%$ extract with $95.68 \%$ of the total phenolic compounds. P-OH-benzoic $(21.14 \%$ of the total phenolic compound) was the highest phenolic compound in methanol $100 \%$ extract. However, catechol $(2.43 \%$ of the total phenolic compound) was the lowest one among the most abundant phenolic compounds in grape seed methanol $100 \%$ extract. Alpha-coumaric(5.46 ppm) and cinnamic $(6.61 \mathrm{ppm})$ were present in trace amount in grape seed methanol $100 \%$ extract.

On the other hand, pyrogallol, $\mathrm{P}-\mathrm{OH}$-benzoic, gallic, catechein, salycillic, chlorogenic and benzoic were the most abundant phenolic compounds in grape seed chloroform $100 \%$ extract represented $81.38 \%$ of the total phenolic compounds. PyrogalIol $(26.07 \%$ of the total phenolic compound) was the highest phenolic compound in chloroform $100 \%$ extract. However, benzoic $(4.18 \%$ of the total phenolic compound) was the lowest one among the most abundant phenolic compounds grape seed chloroform $100 \%$ extract. Also, alphacoumaric (2.57 ppm) and cinnamic (1.43 ppm) were presented in trace amount in the same extract. The corresponding abundant phenolic compounds in case of ethanol $100 \%$ extract are pyrogallol, gallic, salycillic, benzoic, ellagic and $\mathrm{P}-\mathrm{OH}-$ benzoic with $77.04 \%$ of the total phenolic com- 
pounds. Pyrogallol $(22.47 \%$ of the total phenolic compound) was the highest phenolic compound in ethanol $100 \%$ extract. However, P-OH-benzoic (7.05\% of the total phenolic compound) was the lowest one among the most abundant phenolic compounds in ethanol $100 \%$ extract.

Only four major phenolic compounds, i.e. P$\mathrm{OH}$-benzoic, pyrogallol, gallic and catechein were detected with $76.88 \%$ out of total ones in acetone $100 \%$ extract. Another eight of phenolic compounds were detected with moderate level ranged between 24.44 and 69.69 ppm. Meanwhile, the nine lowest phenolic compounds level contained in acetone $100 \%$ extract was ranged between 0.66 and $13.77 \mathrm{ppm}$.

Also, addition of water to pure solvent, i.e. methanol, ethanol and acetone (30, 50 and 50\%, respectively) led to improve the amount of phenolic compounds extracted from grape seeds. Librán et al (2013) reported that highly pure organic solvents $(100 \%)$ could dehydrate the vegetable cells, making difficult the diffusion of polyphenols from the plant material to the extracting liquid. Yilmaz and Toledo (2004) concluded that aqueous solutions of ethanol, methanol were better than a pure compound solvent system for the extraction of phenolic compounds from Muscadine seed. Grape seed methanol $70 \%$ extract had higher phenolic compounds (9301.25 ppm) followed by grape seed ethanol $50 \%$ extract (8199.87ppm). This effect might be attributed to the solvent polarity index. These results indicate methanol $70 \%$ and ethanol
$50 \%$ the best solvents to extract for extracting phenolic compounds from grape seeds. Nageb (2015) reported similar results; i.e. methanol $80 \%$ and ethanol $70 \%$ were more effective than acetone $80 \%$ and ethyl acetate for extracting phenolic compounds from grape pomace. The predominant phenolic compounds that recorded more than 450 ppm for each (nine phenolic compounds) in methanol $70 \%$ extract were $85.75 \%$ out of total ones.

The corresponding percent of nine predominant phenolic compounds (more than $325 \mathrm{ppm}$ ) in ethanol $50 \%$ extract was $89.77 \%$. Meanwhile, $89.83 \%$ was recorded as major nine phenolic compounds (more than $235 \mathrm{ppm}$ ) in acetone 50\% extract.

\section{Identification and quantification of individ- ual flavonoid compounds of grape seed ex- tracts by HPLC technique}

Flavonoid compounds of grape seed extracts as affected by type of solvent were presented in Table (5). Nine flavonoid compounds were identified in each grape seed extract, but the amount was varied according to the type of solvent. Grape seed water extract had the lowest quantity of compounds (128.19 ppm) when compared with other grape seed extracts. Hesperidine was the major flavonoid compound in all extracts (68.9 to 1456.6 ppm) followed by naringin (25.35 to $867.69 \mathrm{ppm}$ ), rutin (23.43 to $406.20 \mathrm{ppm}$ ) and quercetrin (3.33 to $449.65 \mathrm{ppm})$. Methanol $100 \%$ extract had higher flavonoid compounds than other $100 \%$ solvents.

Table 5. Identification of flavonoid compounds (ppm) of grape seeds as affected by solvent type.

\begin{tabular}{|c|c|c|c|c|c|c|c|c|}
\hline $\begin{array}{l}\text { Flavonoid } \\
\text { compounds }\end{array}$ & $\begin{array}{c}\text { Water } \\
\text { Extract }\end{array}$ & $\begin{array}{c}\text { Ethanol } \\
100 \%\end{array}$ & $\begin{array}{c}\text { Ethanol } \\
50 \%\end{array}$ & $\begin{array}{c}\text { Acetone } \\
100 \%\end{array}$ & \begin{tabular}{|c|} 
Acetone \\
$50 \%$
\end{tabular} & $\begin{array}{c}\text { Methanol } \\
100 \% \\
\end{array}$ & \begin{tabular}{|c|} 
Methanol \\
$70 \%$ \\
\end{tabular} & $\begin{array}{c}\text { Chloroform } \\
100 \%\end{array}$ \\
\hline Naringin & 25.35 & 261.84 & 684.85 & 77.06 & 651.93 & 569.4 & 867.69 & 191.86 \\
\hline Rutin & 23.43 & 94.51 & 275.87 & 39.91 & 406.2 & 286.31 & 381.47 & 90.28 \\
\hline Hesperidine & 68.9 & 455.73 & 909.57 & 124.22 & 916.19 & 629.59 & 1456.6 & 493.11 \\
\hline Quercetrin & 3.33 & 52.76 & 289.68 & 9.09 & 449.65 & 222.46 & 308.7 & 82.56 \\
\hline Quercetin & 0.61 & 9.73 & 27.5 & 2.00 & 49.59 & 26.54 & 76.95 & 8.22 \\
\hline Naringenin & 0.38 & 1.98 & 8.85 & 0.44 & 9.42 & 7.20 & 4.28 & 1.23 \\
\hline Hespirtin & 1.96 & 5.82 & 4.23 & 2.35 & 32.76 & 35.9 & 56.17 & 15.34 \\
\hline Kampferol & 2.16 & 9.55 & 31.82 & 4.04 & 18.22 & 28.28 & 46.57 & 12.05 \\
\hline Apigenin & 2.07 & 7.57 & 19.74 & 2.53 & 21.51 & 19.17 & 31.55 & 10.17 \\
\hline Total FC & 128.19 & 899.49 & 2252.11 & 261.64 & 2555.47 & 1824.85 & 3229.98 & 904.82 \\
\hline
\end{tabular}




\section{REFERENCES}

Abdrabba, S.and Hussein, S., 2016.Chemical composition of pulp, seed and peel of red grape from Libya.Global Journal of Scientific Researches, 3(2), 6-11.

A.O.A.C., 2012. "Official Methods of Chemical Analysis". Associated of Official Analytical Chemists, $19^{\text {th }}$ (Ed.), Maryland, USA.

Bartolomé, B.,Nuoez, V., Monagas, M. and Gomez-Cordovés, C., 2004.In vitro antioxidant activity of red grape skins.European Food Res. and Tech., 218, 173-177.

Casazza, A.A., Aliakbarian, B., Mantegna, S., Cravotto, G. and Perego, P., 2010. Extraction of phenolics from Vitisvinifera wastes using non-conventional techniques. J. Food Eng., 100, 150-155.

Centeno, G., M.R., Jourdes, M. Femenia, A., Simal, S., Rosselló, C. and Teissedre, P.L., 2013. Characterization of polyphenols and antioxidant potential of white grape pomace byproducts (Vitis vinifera L.). J. Agric. Food Chem., 61, 11579-11587.

Dwyer, K., Hosseinian, F. and Rod, M., 2014.The market potential of grape waste alternatives., $\mathbf{J}$. Food Res., 3, 91-106.

Huang, Y., Chang, Y. and Shao, Y., 2006. Effect of genotype and treatment on the antioxidant activity of sweet potato in Taiwan. J. Food Chem., 98, 52-53.

Jayaprakasha, G.K., Girennavar, B. and Patil, B.S., 2008. Radical scavenging activities of rio red grapefruits and sour orange fruit extracts in different in vitro model systems.Bioresource and Technol., 99(10), 4484-4494.

Kedage, V.V., Tilak, J.C., Dixit, G.B. Devasagayam, T.P.A. and Mhatre, M.A., 2007. Study of antioxidantproperties of some varieties of grapes (Vitisvinifera L.). Critrical Reviews in Food Sci. and Nutr., 47, 175-185.

Librán, C.M., Luis Mayor, L., Esperanza M. Garcia-Castello and Vidal-Brotons, D., 2013. Polyphenol extraction from grape wastes: Solvent and $\mathrm{pH}$ effect. Agricultural Sciences, 4 (9B), 56-62.

Makris, D.P., Boskou, G. and Andrikopoulos, N.K., 2007. Polyphenolic content and in vitro antioxidant characteristics of wine industry and other agri-food solid waste extracts. Food Comp. and Analy., 20, 125-132.

Mohammedelnour, A.A., Mirghani, M.E.S., Kabbashi, N.A., Alam, Md Z., Musa, K. H. and
Abdullah, A., 2017.Effect of solvent types on phenolics content and antioxidant activities of Acacia polyacanthagum. International Food Research Journal 24(Suppl.), S369-S377.

Nageb, A.M.M., 2015. Using of natural antioxidants for improvement quality of meat products. M.Sc. Thesis, Food Technology Dep., Fac. Agric., Al-Azhar Univ., Egypt, pp. 95-98.

Ovcharova, T., Zlatanov, M. and Dimitrova, R., 2016. Chemical composition of seeds of four Bulgarian grape varieties. Ciência Téc. Vitiv. 31(1), 31-40.

Pereja, O.M.J., Fernandez-Ponce, M.T., Mantell, C. and Enrique, J.M., 2015. Green extraction of antioxidants from different varieties of red grape pomace. Molecules, 20, 9686-9702.

Pinelo, M., Fabbro, P.D., Manzocco, L., Nunez, M.J. and Nicoli, M.C., 2005. Optimization of continuous phenol extraction from Vitis Vinifera byproducts. Food Chem., 92, 109-117.

Radovanović, A., Radovanovic, B. and Jovancicevic, B., 2009. Free radical scavenging and antibacterial activitiesof southern Serbian red wines.Food Chem., 117(2), 326-331.

Rehman, Z.U., 2006. Citrus peel extract- A natural sources of antioxidant. Food Chem., 99(3), 450-454.

Rockenbach, I.I., Rodrigues, E., Gonzaga,L.V., Caliari, V., Maria Inés Genovese, M.I., Gonçalves, A.E. and Fett, R., 2011. Phenolic compounds content and antioxidant activity in pomace from selected red grapes (Vitisvinifera L. and Vitislabrusca L.) widely produced in Brazil. Food Chem., 127, 174-179.

Selcuk, A.R., Demiray, E. and Yilmaz, Y., 2011. Antioxidant activity of grape seeds obtained from molasses (Pekmez) and Winery Production. AkademikGida, 9(5), 39-43.

Teixeira, A, Baenas, N., Dominguez-Perlles, R., Barros, A., Rosa, E., Moreno, D.A., GarciaViguera, C., 2014. Natural bioactive compounds from winery by-product as health promoters. A Review. Int. J. Mol. Sci., 15, 638678.

Titto, J.R., 1985. Phenolic constituents in the leaves of northern willows: methods for the analysis of certain phenolics. J. of Agric. and Food Chem., 33, 213-217.

Uzelac, D.V., Pospisil, J., Levaj, B. and Delonga, K., 2005. The study of phenolic profiles raw apricots and their purees by HPLC for the evaluation of apricot nectars and jams authenticity. Food Chem., 91(2), 373-383. 
Vayupharp, B. and Laksanalamai, V., 2012. Recovery of antioxidants from grape Seeds and its application in fried food. J. Food Process Technol., 3, 4.

Williams, B.W., Cuvelir, M.E. and Berset, C., 1995. Use of a free radical method to evaluate antioxidant activity. LWT-Food Science and Tecnology, 22, 25-30.

Yilmaz, Y. and Toledo, R.T., 2004. Major flavonoids in grape seeds and skins antioxidant capacity of catechin, epicatechin and galic acid. J. Agric. Food Chem., 52, 255-260.
Yu, J., Ahmedna, M., Goktepe, I. and Dai, J., 2006. Peanut skin procyanidins: Composition and antioxidant activities as affected by processing. J. Food Comp. Analy., 19, 364371.

Zulkifli, K.H., Abdullah, N., Abdullah, A., Aziman, N. and Wan Kamarudin, W.S., 2012. Phytochemical screening and activities of hydrophilic and lipophilic antioxidant of some fruit peels. The Malaysian. J. Analy. Sci., (16) 3, $309-317$. 
تقييم بذور العنب كمصدر للمركبات المضادة للأكسدة

[46]

زينب محمد حسن 1- عاطف سعد عشيبه1 - محمد فرج خلاف²- عبدالفتاح عبدالكريم عبدالفتاح²

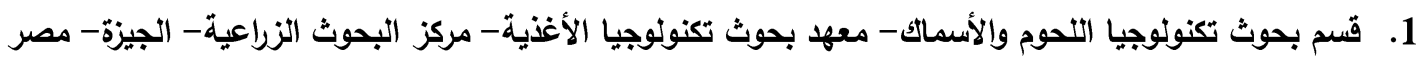

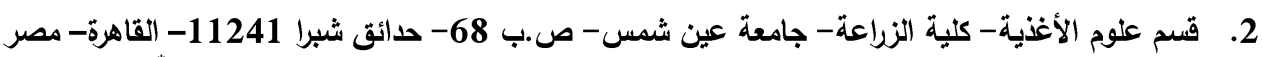
"Corresponding author: zeinabmohamed32@yahoo.com

Received 11 November, 2018, Accepted 17 November, 2018

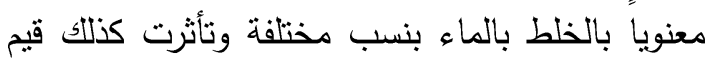

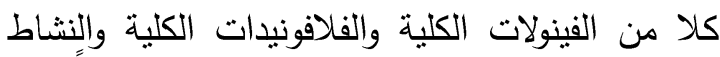

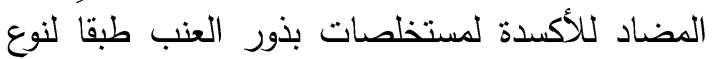

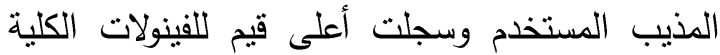

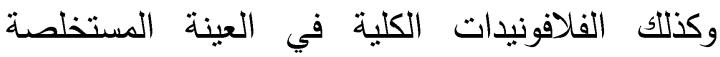

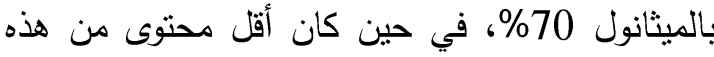
المركبات هو المتواجد في العينة المستخلصة بالماء الماء هاء المقطر فقط.

الكلمات الدالة: مستخلص بذور العنب، المركبات

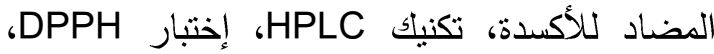
النشاط المضاد للأكسدة، الإستخلاص لأكساك

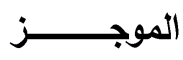

تم إستخلاص بذور العنب بواسطة مذيبات عضوية مختلفة (ميثانول، إيثانول، أسيتون، كلوروفورم) سواء باء

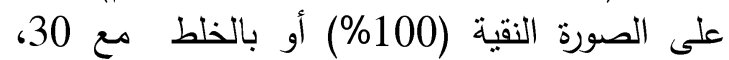
50، 50\% ماء مقطر (فيما عدا الكلورفورم) وتم تقييم محتوى البذور من المركبات المضادة للأكسدة منل ونت فئل

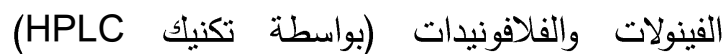
وكذلك النثاط المضاد للأكسدة لهذه المستخلصات (بواسطة اختبار (DPPH).

وتراوحت الكمية المتحصل عليها بين 6-10\% طبقا لنوع المذيب المستخدم وازداد حاصل الاستخلاص لين 